\title{
Photochemical modeling of glyoxal at a rural site: observations and analysis from BEARPEX 2007
}

\author{
A. J. Huisman ${ }^{1, \mathrm{a}}$, J. R. Hottle ${ }^{1, \mathrm{~b}}$, M. M. Galloway ${ }^{1, \mathrm{c}}$, J. P. DiGangi ${ }^{1}$, K. L. Coens ${ }^{1, \mathrm{~d}}$, W. Choi ${ }^{2, \mathrm{e}}$, I. C. Faloona ${ }^{2}$, \\ J. B. Gilman ${ }^{3}$, W. C. Kuster ${ }^{3}$, J. de Gouw ${ }^{3}$, N. C. Bouvier-Brown ${ }^{4, f}$, A. H. Goldstein ${ }^{4}$, B. W. LaFranchi ${ }^{5, g}$, \\ R. C. Cohen ${ }^{5}$, G. M. Wolfe ${ }^{6, h}$, J. A. Thornton ${ }^{6}$, K. S. Docherty ${ }^{7, i}$, D. K. Farmer ${ }^{7, j}$, M. J. Cubison ${ }^{7}$, J. L. Jimenez ${ }^{7}$, \\ J. Mao ${ }^{8, k}$, W. H. Brune ${ }^{8}$, and F. N. Keutsch ${ }^{1}$ \\ ${ }^{1}$ Department of Chemistry, University of Wisconsin-Madison, Madison, Wisconsin, USA \\ ${ }^{2}$ Department of Land, Air, and Water Resources, Univ. of California-Davis, Davis, California, USA \\ ${ }^{3}$ NOAA Earth System Research Laboratory and Cooperative Institute for Research in Environmental Sciences, \\ University of Colorado, Boulder, Colorado, USA \\ ${ }^{4}$ Department of Environmental Science, Policy, and Management, University of California, Berkeley, California, USA \\ ${ }^{5}$ Department of Chemistry, University of California, Berkeley, California, USA \\ ${ }^{6}$ Department of Chemistry, University of Washington, Seattle, Washington, USA \\ ${ }^{7}$ CIRES and Department of Chemistry and Biochemistry, University of Colorado, Boulder, Colorado, USA \\ ${ }^{8}$ Department of Meteorology, Pennsylvania State University, University Park, Pennsylvania, USA \\ ${ }^{a}$ now at: Institute for Atmospheric and Climate Science, ETH Zurich, Zurich, Switzerland \\ ${ }^{b}$ now at: Air Force Office of Scientific Research-Physics and Electronics Directorate, Arlington, Virginia, USA \\ ${ }^{c}$ now at: Chemistry Department, Reed College, Portland, Oregon, USA \\ ${ }^{\mathrm{d}}$ now at: Air Force Space and Missile Systems Center Weather Directorate, Los Angeles, California, USA \\ enow at: Department of Atmospheric and Oceanic Sciences, University of California, Los Angeles, Los Angeles, \\ California, USA \\ ${ }^{f}$ now at: Chemistry \& Biochemistry Department, Loyola Marymount University, Los Angeles, California, USA \\ $\mathrm{g}_{\text {now at: }}$ Center for Accelerator Mass Spectrometry, Lawrence Livermore National Laboratory, Livermore, California, USA \\ ${ }^{\mathrm{h}}$ now at: Department of Chemistry, University of Wisconsin-Madison, Madison, Wisconsin, USA \\ inow at: Alion Science and Technology and EPA Office of Research and Development, Research Triangle Park, \\ North Carolina, USA

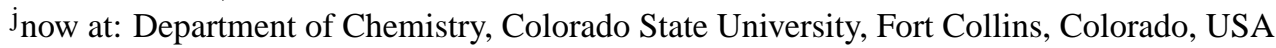 \\ ${ }^{k}$ now at: Program in Atmospheric and Oceanic Sciences, Princeton University, Princeton, New Jersey, USA
}

Received: 29 March 2011 - Published in Atmos. Chem. Phys. Discuss.: 5 May 2011

Revised: 15 August 2011 - Accepted: 22 August 2011 - Published: 1 September 2011

\begin{abstract}
We present roughly one month of high timeresolution, direct, in situ measurements of gas-phase glyoxal acquired during the BEARPEX 2007 field campaign. The research site, located on a ponderosa pine plantation in the Sierra Nevada mountains, is strongly influenced by biogenic volatile organic compounds (BVOCs); thus this data adds to the few existing measurements of glyoxal in BVOCdominated areas. The short lifetime of glyoxal of $\sim 1 \mathrm{~h}$, the fact that glyoxal mixing ratios are much higher during high temperature periods, and the results of a photochemi-
\end{abstract}

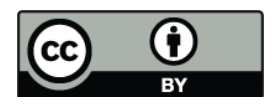

Correspondence to: F. N. Keutsch (keutsch@chem.wisc.edu) cal model demonstrate that glyoxal is strongly influenced by BVOC precursors during high temperature periods.

A zero-dimensional box model using near-explicit chemistry from the Leeds Master Chemical Mechanism v3.1 was used to investigate the processes controlling glyoxal chemistry during BEARPEX 2007. The model showed that MBO is the most important glyoxal precursor $(\sim 67 \%)$, followed by isoprene $(\sim 26 \%)$ and methylchavicol $(\sim 6 \%)$, a precursor previously not commonly considered for glyoxal production. The model calculated a noon lifetime for glyoxal of $\sim 0.9 \mathrm{~h}$, making glyoxal well suited as a local tracer of VOC oxidation in a forested rural environment; however, the modeled glyoxal mixing ratios over-predicted measured glyoxal by a factor 2 to 5 . Loss of glyoxal to aerosol was not found

Published by Copernicus Publications on behalf of the European Geosciences Union. 
to be significant, likely as a result of the very dry conditions, and could not explain the over-prediction. Although several parameters, such as an approximation for advection, were found to improve the model measurement discrepancy, reduction in $\mathrm{OH}$ was by far the most effective. Reducing model $\mathrm{OH}$ concentrations to half the measured values decreased the glyoxal over-prediction from a factor of 2.4 to 1.1 , as well as the overprediction of $\mathrm{HO}_{2}$ from a factor of 1.64 to 1.14 . Our analysis has shown that glyoxal is particularly sensitive to $\mathrm{OH}$ concentration compared to other BVOC oxidation products. This relationship arises from (i) the predominantly secondary- or higher-generation production of glyoxal from (mainly $\mathrm{OH}$-driven, rather than $\mathrm{O}_{3}$-driven) BVOC oxidation at this site and (ii) the relative importance of photolysis in glyoxal loss as compared to reaction with $\mathrm{OH}$. We propose that glyoxal is a useful tracer for $\mathrm{OH}$-driven BVOC oxidation chemistry.

\section{Introduction}

Ozone $\left(\mathrm{O}_{3}\right)$ and aerosols influence climate (Intergovernmental Panel on Climate Change, 2007) and have a direct impact on human health (Bates, 1993; Jakab et al., 1995) and the biosphere (Karnosky et al., 1996; Percy et al., 2002). It is well established that the formation of $\mathrm{O}_{3}$ and secondary organic aerosol (SOA), which is an important component of ambient aerosol (Zhang et al., 2007), are both directly tied to the gas-phase oxidation of volatile organic compounds (VOCs), in particular in the VOC- $\mathrm{HO}_{\mathrm{x}}-\mathrm{NO}_{\mathrm{x}}$ catalytic cycle $\left(\mathrm{HO}_{\mathrm{x}} \equiv \mathrm{OH}+\mathrm{HO}_{2}, \mathrm{NO}_{\mathrm{x}} \equiv \mathrm{NO}+\mathrm{NO}_{2}\right)$ (Kroll and Seinfeld, 2008; Wood et al., 2010; Herndon et al., 2008). Substantial challenges remain, however, in modeling SOA (de Gouw et al., 2005; Volkamer et al., 2006; Goldstein and Galbally, 2007; Carlton et al., 2009; Hallquist et al., 2009) and $\mathrm{O}_{3}$ away from urban centers (e.g., Trainer et al., 1987; Plummer et al., 1996). The challenges for $\mathrm{O}_{3}$ are especially pronounced in rural, forested areas with high biogenic VOC emissions, e.g., terpenes, isoprene, and 2-methyl-3-buten-2ol (MBO), which together constitute the majority of global non-methane VOC emissions (Guenther et al., 2000). The failure of models in rural vegetated regions, where BVOC and aldehyde reactivity dominates (Steiner et al., 2008) indicates that more attention needs to be paid to primary emissions of oxygenated VOC and the secondary production of oxygenates, of which $\alpha$-dicarbonyls are a subset.

Glyoxal, the smallest ( $\alpha$-)dicarbonyl, has a lifetime of only a few hours with respect to photolysis and reaction with $\mathrm{OH}$. Thus, glyoxal can be viewed as a local tracer of VOC oxidation chemistry, which is advantageous for comparisons between models and measurements. According to commonly used mechanisms available in the literature, such as the National Center for Atmospheric Research (NCAR) Master Mechanism, Leeds Master Chemical Mechanism
(MCM), and the Mainz Isoprene Mechanism 2 (Madronich and Calvert, 1990; Bloss et al., 2005a,b; Taraborrelli et al., 2009) daytime glyoxal production from BVOCs proceeds largely via reaction of $\mathrm{OH}$, while reaction with ozone contributes relatively little, making glyoxal a promising tracer of OH-driven BVOC oxidation. Furthermore, these mechanisms treat glyoxal solely as a higher generation oxidation product of isoprene, MBO and terpenes. All stages of VOC oxidation can contribute to $\mathrm{O}_{3}$ formation, and, for example for isoprene, more than one oxidation step is required to reduce the volatility of products to the extent that partitioningdriven SOA formation is expected (e.g., Claeys et al., 2004; Edney et al., 2005; Paulot et al., 2009). Thus, glyoxal measurements in rural, forested regions can provide a local tracer of VOC oxidation chemistry, and may be used to test our understanding of higher generation oxidation processes.

In addition to the challenges of modeling ozone in forested areas dominated by BVOCs, there recently has been much focus on the often large discrepancies between measured and modeled $\mathrm{OH}$ radical concentrations in areas dominated by BVOCs, especially isoprene (Tan et al., 2001; Thornton et al., 2002; Ren et al., 2008; Lelieveld et al., 2008; Hofzumahaus et al., 2009; Peeters et al., 2009; Paulot et al., 2009; Peeters and Muller, 2010; Archibald et al., 2010; Stavrakou et al., 2010; da Silva, 2010; Whalley et al., 2011). Models typically underpredict $\mathrm{OH}$, sometimes by up to an order of magnitude (Lelieveld et al., 2008; Whalley et al., 2011), relative to observations. A model of atmosphere-forest exchange for the measurement site of the work described here under-predicts $\mathrm{OH}$ by a factor of six (Wolfe et al., 2011). As $\mathrm{OH}$ radicals are the major oxidizing species in the troposphere this disagreement has large implications for the ability of models to accurately reproduce BVOC oxidation and resulting $\mathrm{O}_{3}$ and SOA formation. A recent intercomparison of the different techniques employed for measuring ambient $\mathrm{OH}$ showed slopes in the linear regressions of the daytime measurements of different instruments of 1.01-1.13 for experiments in the SAPHIR chamber and 1.06-1.69 for ambient measurements (Schlosser et al., 2009). This demonstrates that $\mathrm{OH}$ continues to prove difficult to measure under all conditions. Clearly, BVOC oxidation and hence production of BVOC oxidation products (OVOCs) depends critically on oxidant concentrations, with $\mathrm{OH}$ being of central importance. Thus, using OVOCs as tracers of BVOC oxidation can provide insight into how rapidly BVOC oxidation is occurring, and, if the OVOCs are produced primarily via reaction of $\mathrm{OH}$ with BVOCs, their formation will in turn reflect ambient $\mathrm{OH}$ concentrations.

In addition to its use as tracer of VOC oxidation chemistry, glyoxal also is of current interest due to its potential direct contribution to SOA formation (Carlton et al., 2007; Volkamer et al., 2007; Corrigan et al., 2008; Nozière et al., 2008; Galloway et al., 2009; Shapiro et al., 2009; Tan et al., 2009). In models of SOA formation that include glyoxal, it is often a substantial contributor (Carlton et al., 2007; Volkamer et al., 
2007; Fu et al., 2008; Ervens and Volkamer, 2010). It is thus important to validate glyoxal concentrations and chemistry in models by comparison with field-measurements. As model studies show that oxidation of BVOCs contributes the majority of glyoxal on a global scale (Fu et al., 2008; Myriokefalitakis et al., 2008; Stavrakou et al., 2009) a comparison with glyoxal measurements for biogenic regions is particularly important.

The site of the Biosphere Effects on AeRosols and Photochemistry EXperiment (BEARPEX) 2007 field campaign, near Blodgett Forest Research Station (BFRS) in the Sierra Nevada, California, is located in a region influenced by high $\mathrm{BVOC}$ emissions, in particular of $\mathrm{MBO}$ and isoprene as well as terpenes (Lamanna and Goldstein, 1999; Holzinger et al., 2005; Bouvier-Brown et al., 2009) with regular and well characterized meteorology. There have been a number of studies detailing the BVOCs observed at the site (Lamanna and Goldstein, 1999; Holzinger et al., 2005; Bouvier-Brown et al., 2009) making the location ideal for a detailed study of BVOC oxidation.

In this paper we present the first fast $(<1 \mathrm{~min})$, high sensitivity, direct in situ measurements of glyoxal, taken using the Madison Laser-Induced Phosphorescence (MAD-LIP) Instrument (Huisman et al., 2008). We present a description of this new type of data-set for glyoxal, which provides a new point of intercomparison for models in a region dominated by BVOCs. We also present an analysis that investigated the factors influencing glyoxal concentrations at the site and employ glyoxal as a local tracer of VOC oxidation chemistry at the site, in particular with respect to oxidant levels and the sensitivity of model glyoxal concentrations to $\mathrm{OH}$.

\section{Measurements site and methods}

\subsection{Site description}

Glyoxal mixing ratios were measured during the BEARPEX 2007 campaign at a research site located on a ponderosa pine plantation in the Sierra Nevada mountains, $\sim 80 \mathrm{~km}$ east of Sacramento, CA $\left(38^{\circ} 53^{\prime} 42.9^{\prime \prime} \mathrm{N}, 120^{\circ} 37^{\prime} 57.9^{\prime \prime} \mathrm{W}\right)$. The site, on Sierra Pacific Industries land, is at an elevation of $1315 \mathrm{~m}$ and is near the Blodgett Forest Research Station (BFRS) and has been described in detail previously (Goldstein et al., 2000). It experiences a Mediterranean climate which is typically hot and dry during the summer before transitioning to a cool, wet period starting in September. During the summer, daytime wind is consistently out of the west to southwest while nighttime wind is easterly to northeasterly. The cycling of polluted air from the Central Valley that arrives in late afternoon and clean air from upslope at night leads to regular diurnal patterns in many trace gases (e.g., Lamanna and Goldstein, 1999; Dillon et al., 2002; Murphy et al., 2007; Wolfe et al., 2009).

\subsection{Madison LIP instrument}

Glyoxal data were collected using the Madison LIP Instrument, which has been described in detail elsewhere (Huisman et al., 2008). Briefly, gas phase glyoxal was detected via laser-induced phosphorescence and gated photon counting using a white-type multipass cell. The inherent spectral and temporal resolution of the phosphorescence signal allowed a limit of detection $(3 \sigma)$ of $18 \mathrm{ppt}_{\mathrm{v}}$ in 1 min during the BEARPEX 2007 deployment. For the BEARPEX 2007 deployment, the tower portion of the Madison LIP Instrument was initially situated near the south tower, which was $10 \mathrm{~m}$ south of the main scaffold tower, on which all measurements to which we compare our data were made except meteorology. The inlet consisted of either $7.6 \mathrm{~m}$ or $1 \mathrm{~m}$ of $1 / 2$ in OD PTFE tube with no filters of any kind. Field tests showed no discernible inlet effects with respect to length of inlet (cf. Huisman et al., 2008) and more recent tests have provided additional evidence that the length and material of inlet have negligible effect on the glyoxal signal. While the instrument was near the tower, it used an inlet ( $7.6 \mathrm{~m} \mathrm{1/2}$ in PTFE tube) at $3.7 \mathrm{~m}$ above ground level (a.g.l.) on the tower, where it remained from 24 August-18 September (day of year, DOY, 236 to DOY 261. After 18 September the instrument was placed on the tower, where it remained until the end of glyoxal measurements on 27 September, DOY 270, with a short $(1 \mathrm{~m})$ inlet at $12.0 \mathrm{~m}$ a.g.l. Tests carried out in the field show that the data from $3.7 \mathrm{~m}$ and $12 \mathrm{~m}$ a.g.l. were comparable during the daytime, though not necessarily identical (Huisman et al., 2008).

\subsection{Other measurement techniques}

A suite of measurements was available for BEARPEX 2007, including meteorological parameters, such as wind speed and direction, air temperature, humidity, and ozone concentration. Volatile organic compounds where measured using two gas chromatographs with quadrupole mass spectrometers (GC-MS). Speciated acyl peroxy nitrate (APN) measurements were obtained via a thermal dissociation-chemical ionization mass spectrometer. Laser-induced fluorescence instrumentation was used for measurements of $\mathrm{OH}, \mathrm{HO}_{2}$ and $\mathrm{NO}_{2}$. Oxygenated organic aerosol (OOA) and hydrocarbonlike organic aerosol (HOA) were obtained using an Aerodyne high-resolution time-of-flight aerosol mass spectrometer. Aerosol surface area was estimated using a scanning mobility particle sizer and observations of boundary layer height were obtained from temperature, humidity, and wind profiles obtained with a tethersonde during BEARPEX 2007. Details of the instrumentation and methods used to obtain these data can be found in Supplement Sect. 1.1. 


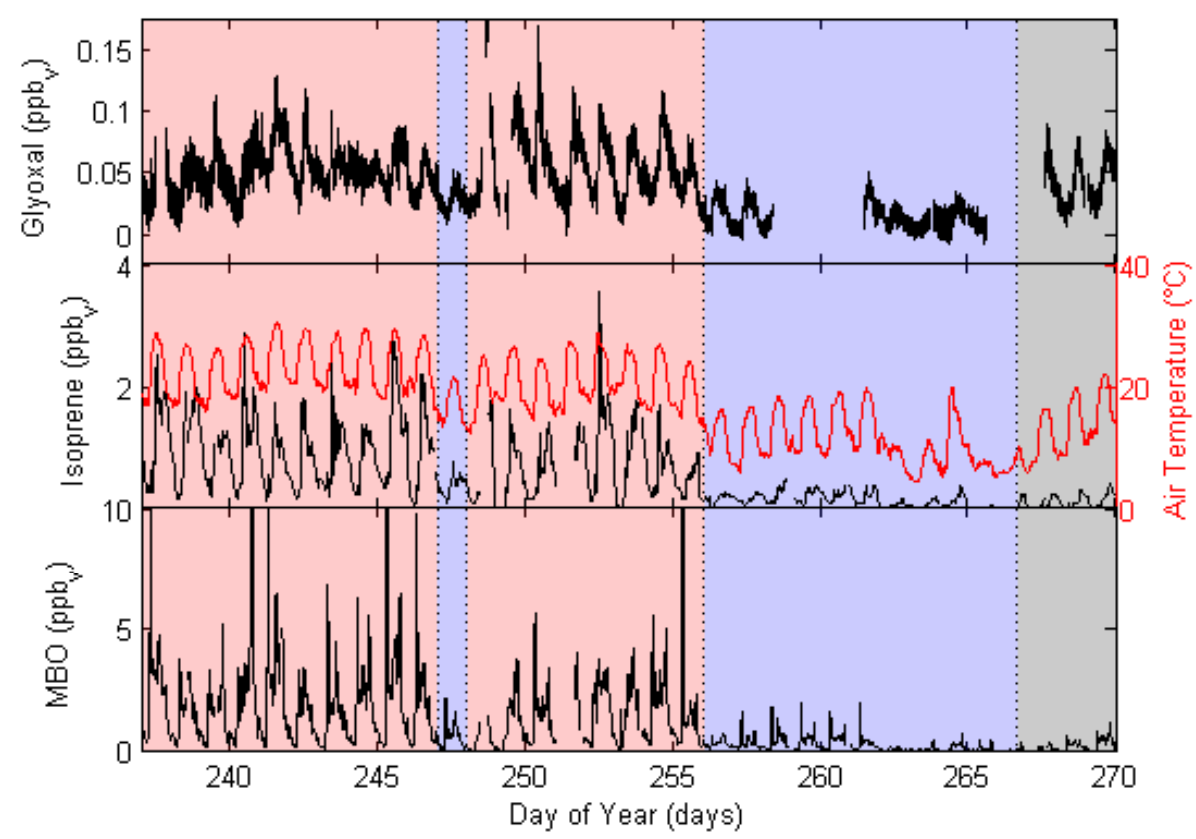

Fig. 1. Overview of glyoxal measurements, separated by temperature period (red, blue, gray corresponding to hot, cold, and intermediate period). Isoprene and $\mathrm{MBO}$, the most important glyoxal BVOC precursors, are included along with air temperature on the center axis on right.

\section{Observations at BEARPEX 2007}

\subsection{General observations}

There is only limited glyoxal data available in rural settings and to our knowledge we present the first such data obtained that has a high time resolution obtained with an instrument utilizing a direct, in situ detection method. The complete dataset for glyoxal is presented in Fig. 1 along with ambient temperature and the biogenic VOCs isoprene and MBO, which were the major precursors of glyoxal at the site. Meteorological conditions at BRFS were dry and hot for the majority of the period for which glyoxal data was collected. An abrupt change in weather occurred around DOY 256 (13 September), after which temperatures were substantially lower. The data were divided into a "hot", "cold" and "intermediate" period as defined in the following: the hot period, DOY 240-246 and 248-256, had an average high and low temperature of $\sim 27$, and $\sim 18^{\circ} \mathrm{C}$, respectively. The cold period, DOY 247, 256-257, 261-266, had an average high and low temperature of $\sim 15$, and $\sim 8^{\circ} \mathrm{C}$, respectively. No measurements were taken on DOY 258-261. The intermediate period, DOY 267-270, had an average high and low temperature of $\sim 19$, and $\sim 9^{\circ} \mathrm{C}$, respectively, closer to the cold than the hot period, but the data set was separated from the cold period because of substantially higher glyoxal mixing ratios. The cause of the higher glyoxal mixing ratios during the intermediate period remains unclear, as the average diurnal temperature and VOC profile of this period resem- bles that of the cold period. The raw data from the Madison LIP Instrument did not show an offset and instrument data logs indicated normal operation during this period, which followed the first rain falls of the season. The substantial change in temperature from hot to cold period provides a basis for studying the dependence of glyoxal concentrations on biogenic emissions, which are strongly tied to temperature (e.g., Guenther et al., 1991; Schade et al., 2000).

The complete dataset for glyoxal, which spans DOY 236270 , had strong diurnal trends with mean of $43.6 \mathrm{ppt}_{\mathrm{v}}$ and median of 41.2 ppt $_{\mathrm{v}}$ with $95 \%$ bounds of the complete set of $4.6 \mathrm{ppt}_{\mathrm{v}}$ to $121.7 \mathrm{ppt}_{\mathrm{v}}$ (see Table 1). The measurement uncertainty was $\sim 20 \%$. A previous measurement at this site by Spaulding et al. (2003) found glyoxal mixing ratios of 6-83 $\mathrm{ppt}_{\mathrm{v}}$ during 10 days in August and September 2000, with average mixing ratio $27 \pm 15 \mathrm{ppt}_{\mathrm{v}}$ and a diurnal profile weaker than that observed here. The previous measurements, although occurring in a different year and with different mean temperatures than those reported here, are still within one standard deviation of our mean observations.

The BEARPEX 2007 campaign was located in a region with high BVOC emissions, in particular the glyoxal precursors isoprene and MBO. Thus a strong influence of BVOCs is expected on glyoxal at the site and comparison of the hot and cold period confirmed this (see Fig. 2): there is a large difference between hot and cold period in BVOC concentrations and OVOCs that only form from BVOCs, e.g., isoprene, MBO, MVK. Glyoxal shows a similar, but somewhat smaller difference, whereas the anthropogenic tracer propene showed 


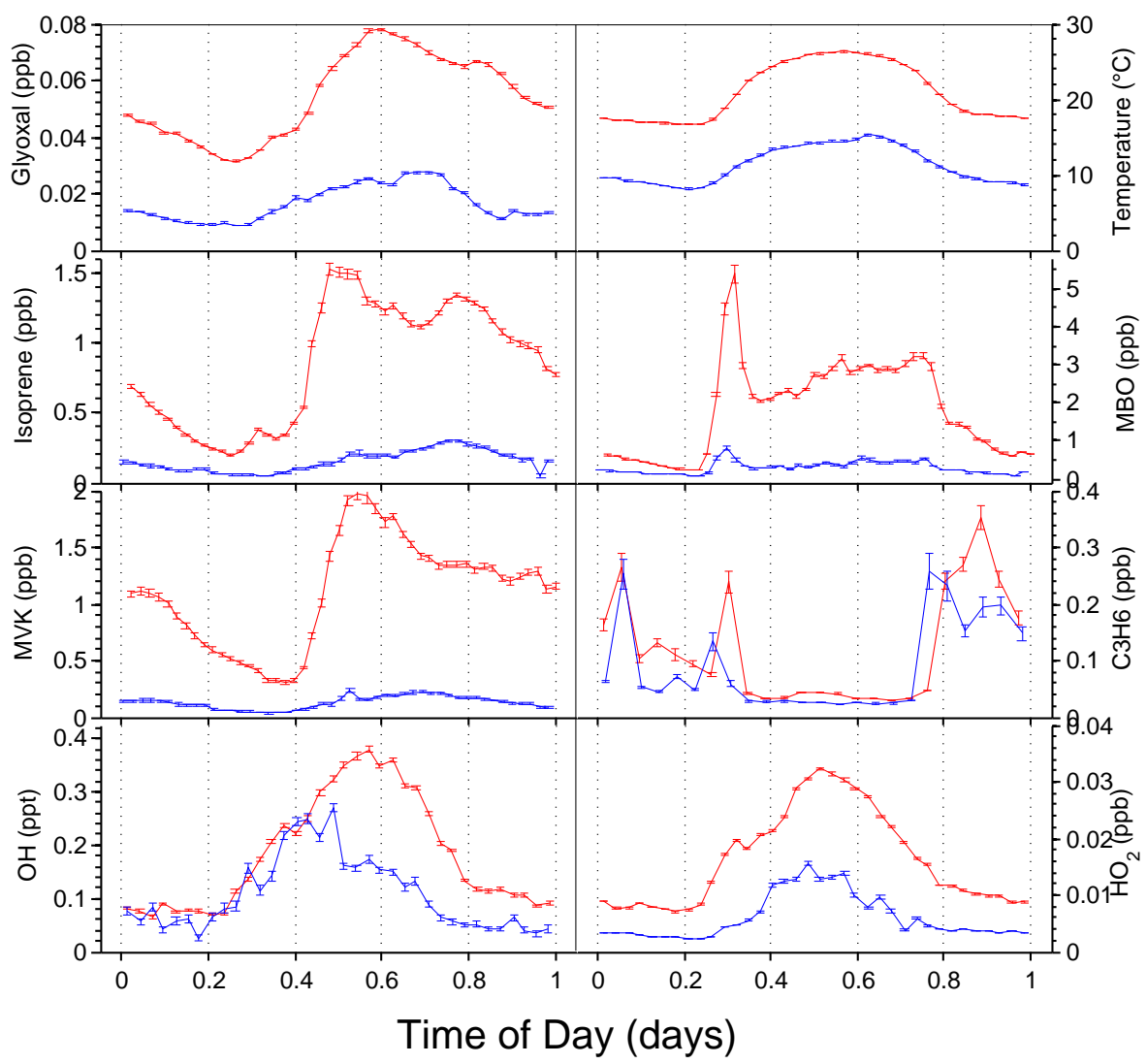

$$
\text { Hot }- \text { Cold }
$$

Fig. 2. Diurnal averages of glyoxal, temperature, example biogenic and anthropogenic species, and $\mathrm{HO}_{\mathrm{x}}$ separated into hot and cold period. Here the hot period spans 15 days. The cold period contains only data for which glyoxal was recorded. Error bars indicate the 1 standard deviation envelope as calculated based on the variability in the data from day to day and neglecting reported or calculated error from each measurement.

quite different behavior (see Fig. 2). Similarly, daytime concentrations of toluene at the site were essentially unchanged between the two periods, as were those of benzene and other anthropogenic precursors/tracers. Thus, the measurements qualitatively support that there was a strong biogenic influence on glyoxal at the site, and the results from the photochemical model described in Sect. 4.1 supports this.

The correlation of half-hourly glyoxal measurements to measurements of known glyoxal BVOC precursors and BVOC oxidation products were high, whereas correlations with known anthropogenic glyoxal precursors, such as toluene, benzene and acetylene were lower. During the hot period, the strongest correlation was observed with the BVOC oxidation products MPAN $\left(R^{2}=0.59, n=\right.$ 362 points), and $\operatorname{MVK}\left(R^{2}=0.41, n=671\right)$, whereas correlations with anthropogenic tracers were substantially smaller (see Table S1). Hot (and cold) period glyoxal was very poorly correlated $\left(R^{2}<0.10\right)$ with the total OA and OOA factors as measured by Aerosol Mass Spectrometer (AMS) (see Table S1). In addition to the poorer correlations of gly-
Table 1. Glyoxal dataset parameters by temperature period, all values in pptv.

\begin{tabular}{lccc}
\hline Period & Mean & \multicolumn{2}{c}{$95 \%$ bounds } \\
& & Lower & Upper \\
\hline Campaign & 43.6 & 4.6 & 121.7 \\
Hot & 53.9 & 22.3 & 127.3 \\
Cold & 16.3 & 0.9 & 48.4 \\
Intermediate & 42.1 & 19.4 & 93.4 \\
\hline
\end{tabular}

oxal with anthropogenic glyoxal precursors, the concentrations of these precursors were low, so that production rates from the BVOCs were much higher, as discussed in Sect. 4.1.

\subsection{Deposition}

The profile of glyoxal on many nights approximated a simple exponential decay, allowing an inference of the deposition 


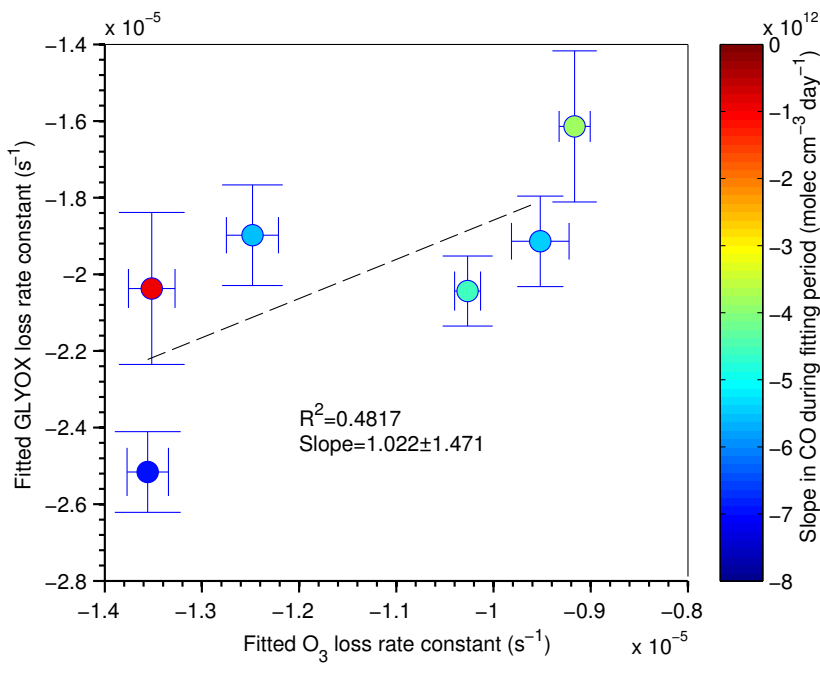

Fig. 3. Fitted deposition rates for glyoxal and $\mathrm{O}_{3}$ from data taken at BEARPEX 2007. Color coding of points indicates the slope in CO, an indicator of the stability or dilution of the airmass.

rate by fitting in analogy to the method used by Sumner et al. (2001). Six nights were selected which could be fit well with a single-exponential decay in both glyoxal and $\mathrm{O}_{3}$. The results of these fits are presented in Fig. 3, which also includes information on the slope of measured $\mathrm{CO}$ during the fitting period ( 0.8 to $0.2 \mathrm{~d} ; 19.2$ to $4.6 \mathrm{~h}$ ), on a given night in the color of each point. It seems likely that those points exhibiting the least slope in $\mathrm{CO}$ indicate a consistent airmass, a requirement for using the decay to fit deposition. The average correlation coefficient between the inferred deposition rates of glyoxal and $\mathrm{O}_{3}$, which were calculated independently, within each night was good $\left(R^{2}=0.68\right)$, in agreement with the results of Sumner et al. (2001) for formaldehyde, but the overall correlation was relatively poor $\left(R^{2}=0.48\right.$, $n=6$ nights). Thus there was some degree of variability between the relative deposition rates of both glyoxal and $\mathrm{O}_{3}$ on different nights, likely arising from the different processes which control the loss of each compound, such as reactions of $\mathrm{O}_{3}$ with biogenic VOC (Fares et al., 2010) or loss of glyoxal to surfaces. We did not observe a relationship between $\mathrm{RH}$ and deposition rate of glyoxal, but this is not necessarily conclusive as we have only six points (corresponding to six nights).

The average of the fitted exponential loss rate in glyoxal was $-2.14 \times 10^{-5} \pm 2.7 \times 10^{-6} \mathrm{~s}^{-1}$, which (assuming a nocturnal boundary layer of $70 \mathrm{~m}$, Choi et al., 2010b) corresponded to a deposition velocity of approximately $0.15 \mathrm{cms}^{-1}$, reasonably consistent with the value of Volkamer et al. (2007) of $0.3 \mathrm{cms}^{-1}$. Equating the observed exponential decay to deposition in this manner assumes that there are no important production or loss processes, except for deposition. The photochemical model described in Sect. 4 required a deposition rate which was double that inferred here to match the observed loss rate. This difference arises from the incorrect assumption in this analysis that no glyoxal is produced at night; in fact the average predicted nighttime production rate was approximately $10 \%$ of the average noontime rate. The photochemical model described in Sect. 4 showed that deposition velocity of $0.3 \mathrm{cms}^{-1}$ was required to reproduce the observed loss rate, as according to the model there was slow nighttime glyoxal production.

\section{Photochemical box model}

We employed a photochemical model based on the reactions and kinetics in the Master Chemical Mechanism (MCM) v. 3.1 (Jenkin et al., 1997; Saunders et al., 2003) for comparison with observations to gain insight into the processes controlling glyoxal concentrations during BEARPEX 2007 and to evaluate the degree to which the MCM can be used to represent glyoxal in this rural setting. The model used the full MCM chemistry for the following species and their oxidation products: isoprene, $\mathrm{MBO}, \alpha$-pinene, $\beta$-pinene, acetylene $\left(\mathrm{C}_{2} \mathrm{H}_{2}\right)$, benzene, and toluene. In addition to well-known biogenic precursors of glyoxal such as $\mathrm{MBO}$ and isoprene, we included methylchavicol, an oxygenated aromatic BVOC which was present in substantial concentrations (mean daily maximum of $\sim 0.3 \mathrm{ppb}_{\mathrm{v}}$, with $\sim 0.6 \mathrm{ppb}_{\mathrm{v}}$ as highest observed mixing ratio) during BEARPEX 2007 (Bouvier-Brown et al., 2009). Oxidation of methylchavicol by $\mathrm{OH}$ produces glycolaldehyde (see mechanism, Fig. S3) with a direct yield of $37 \%$ (Lee et al., 2006). While methylchavicol does not yield as much glycolaldehyde as $\mathrm{MBO}$, which has a corresponding direct yield of $\sim 65 \%$ (Chan et al., 2009), it can produce additional glyoxal via higher-generation oxidation processes involving the aromatic system (see Fig. S3).

In all cases, the model was driven using half-hourly averaged observations of $\mathrm{O}_{3}$, VOCs, campaign diurnally averaged $\mathrm{NO}_{2}$, and temperature-period diurnally averaged $\mathrm{OH}$ (cf. Sect. 2 for measurement techniques and Sect. 3.1 definition of temperature periods). Different subsets of precursor VOCs were used to explore their influence and determine the main glyoxal VOC precursors. $\mathrm{HO}_{2}$ and intermediates such as MVK were not driven to follow observations, providing comparisons of model and observations in addition to glyoxal. The model used the MCM in conjunction with standard $\mathrm{HO}_{\mathrm{x}}-\mathrm{NO}_{\mathrm{x}}$ cycling with (a) adjustment of yields and production mechanism of glyoxal from isoprene and glycolaldehyde following Galloway et al. (2011), (b) adjustment of MPAN $+\mathrm{OH}$ rate constant following the recommendation of Orlando et al. (2002), (c) inclusion of dry deposition, (d) inclusion of loss of gas phase glyoxal to aerosol based on Volkamer et al. (2007), (e) diurnal dilution factor following Pérez et al. (2009), (f) inclusion of methylchavicol degradation chemistry. Details of the implementation are presented in Supplement Sect. 1.2. The model was allowed to "spinup" to provide approximate starting concentrations for those 


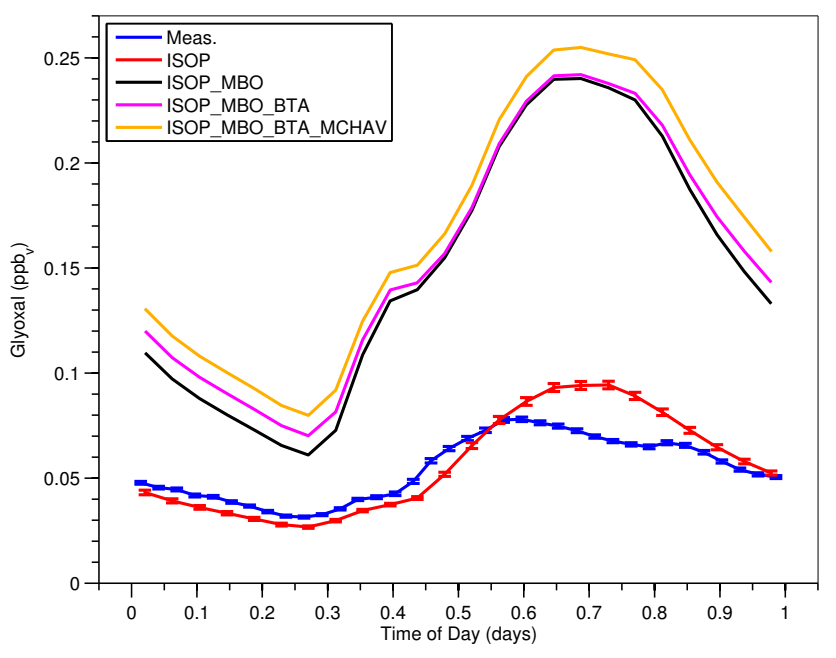

Fig. 4. Diurnally averaged model results from the hot period showing the incremental contributions of various VOC precursors. The model VOC precursor subsets correspond to: ISOP = isoprene; $\mathrm{MBO}=\mathrm{MBO} ; \mathrm{BTA}=$ benzene, toluene, acetylene, and pinenes; $\mathrm{MCHAV}=$ methylchavicol. Error bars are omitted from upper traces for clarity, all are approximately equal in magnitude to those shown for that of ISOP. The form and magnitude of MBO alone is similar to that of ISOP + MBO.

species for which no measurements were available by looping over the same one hour period 25 times. After this equilibration, any species for which measurements were available were again set to match observation. This model was able to match glyoxal data taken by the Madison LIP Instrument in an identical operational configuration taken at the Caltech Environmental Chambers for experiments of isoprene and MBO oxidation (the dominant precursors of glyoxal at BFRS) under both NO rich and NO poor conditions (Galloway et al., 2011).

\subsection{Base-case box model results}

The optimized 0-D MCM-based box model described above was used to simulate BEARPEX 2007 conditions. The diurnally averaged model results for the hot period are shown together with the corresponding glyoxal measurement in Fig. 4. The model predicted the following apportionment of production of glyoxal from precursor VOCs (and their oxidation products) during the hot period when all precursors listed in Sect. 4 were included: $66.8 \%$ MBO, $17.7 \%$ highergeneration production from isoprene, $6.3 \%$ direct isoprene, $5.5 \%$ methylchavicol, and $3.7 \%$ other (less than $1 \%$ each). The anthropogenic VOCs benzene and toluene, as well as acetylene and the pinenes only contributed to a small degree. Although methylchavicol was a small source, contributing about $6 \%$ of glyoxal, it was the third most important precursor VOC. Glycolaldehyde was the most important immediate precursor for glyoxal $(\sim 90 \%)$, and $\sim 75 \%, \sim 17 \%, \sim 6 \%$, of glycolaldehyde arise from MBO, isoprene and methylchavicol oxidation, respectively. Altogether, these results corroborated the notion that the majority of hot period glyoxal production during BEARPEX 2007 was biogenic in nature, dominated by production from $\mathrm{MBO}$ and isoprene.

According to the model, glyoxal had a short $(\sim 0.9 \mathrm{~h})$ daytime lifetime. The calculated average loss rate and equivalent lifetime in hours as a function of time of day for glyoxal are displayed in Fig. S5. The nighttime loss rate was dominated by reaction with $\mathrm{OH}$ and by deposition (cf. discussion of deposition in Sect. 3.2), while daytime loss rate was driven by photolysis, reaction with $\mathrm{OH}$, and dilution with background air (Pérez et al., 2009), all contributing about equally at noon, and aerosol uptake contributing about half of each of the former. The short lifetime of glyoxal makes it ideally suited as a local tracer of VOC oxidation chemistry.

A striking feature of Fig. 4 is the degree of over-prediction of the model compared to the measurements, which is significantly outside of the measurement uncertainty of $20 \%$. In the following section we describe a sensitivity analysis of the parameters that were found to be most effective at influencing this over-prediction using only isoprene and $\mathrm{MBO}$ as glyoxal precursors. Using the full set of precursor VOCs, with a resulting 1005 species in the MCM was much more computationally demanding than using only $\mathrm{MBO}$ and isoprene (219 species in the MCM). In addition, MBO and isoprene contributed the majority of the over-prediction as they produced ca. $90 \%$ of glyoxal.

\subsection{Model sensitivity analysis}

In this section we present an analysis of which model parameters were found to most strongly influence the model over-prediction of glyoxal. The following sinks and sources were investigated but found not to substantially contribute to the over-prediction:

- In order for low $\mathrm{NO}_{\mathrm{x}}$ chemistry to lower glyoxal noticeably, unphysical (i.e. faster than gas kinetic) rate constants for the $\mathrm{RO}_{2}+\mathrm{HO}_{2}$ reaction had to be employed. We did not alter the $\mathrm{HO}_{\mathrm{x}}+\mathrm{HO}_{\mathrm{x}}$ termination rate. In addition, the model employed here matched glyoxal production in low $\mathrm{NO}_{\mathrm{x}}$ chamber studies of MBO and isoprene very well (Galloway et al., 2011).

- Decreasing glyoxal concentrations noticeably by increased mixing with background air via "vertical dilution" required a dilution rate constant much larger $(\sim 5 \mathrm{x})$ than that used in other studies (Dillon et al., 2002; Pérez et al., 2009), which is unlikely to be correct.

- Increasing the daytime deposition velocity by an order of magnitude from the measured nighttime values in view of the recent work by Karl et al. (2010) had only a marginal $(\sim 10 \%)$ effect. 
- Reducing the glyoxal yield for the reaction of $\mathrm{OH}$ with glycolaldehyde clearly reduced glyoxal concentrations, however, a reduction to a yield of $0.045(\sim 15 \%$ nominal) was required to achieve agreement with average glyoxal measurements. In addition, the nominal yield of 0.29 in the model was calculated from chamber experiments of MBO oxidation which included glycolaldehyde measurements following BEARPEX 2007 with no observable change in instrument performance and hence should be optimized for this study. In other words, even if the measured glyoxal concentration is biased by some unknown systematic error, analysis of instrument performance strongly indicates that this should match between the field and chamber studies.

The sensitivity of model glyoxal to three parameters will be discussed in more detail: gas-to-aerosol partitioning, altered $\mathrm{OH}$ radical concentration, and a treatment of transport.

\subsubsection{Gas-to-aerosol partitioning}

Loss to aerosol has been proposed as an important sink of glyoxal in Mexico City (Volkamer et al., 2007). However, a number of factors were expected to make aerosol less important as a sink during BEARPEX 2007: the aerosol surface areas were about an order of magnitude lower (average aerosol surface areas of $\sim 100-200 \mathrm{~mm}^{2} \mathrm{~m}^{-3}$ ). It has been demonstrated that glyoxal uptake mainly depends on aerosol liquid water content (Volkamer et al., 2009), which is expected to be quite low for the dry conditions at BEARPEX 2007 (average daytime and nighttime relative humidity $24.2 \pm 5.6 \%$ and $45.7 \pm 10.1 \%$, respectively). These facts imply that aerosol loss was not an important sink term for glyoxal during BEARPEX 2007. Additional insight into the role of aerosol as a sink for glyoxal was obtained by analyzing the difference between measured and modeled glyoxal as a function of observed aerosol surface area in model runs that did not include an aerosol loss term (see Fig. S2). If aerosol loss corresponded to an important sink of glyoxal, modelmeasurement agreement should degrade at high aerosol surface areas. However, this was not the case, in fact a small opposite trend was observed. As a result an increase in the aerosol sink term may improve the average glyoxal overprediction but does so by overcorrecting during periods with higher aerosol load and hardly affecting the over-prediction during periods of low aerosol loads. This finding together with the low relative humidities make it unlikely that aerosol loss was one of the main contributors to the over-prediction. However, if glyoxal can be taken up into aerosol under the dry conditions during BEARPEX 2007, a higher value of $\gamma$ would contribute to improving the average discrepancy between model and measurement.
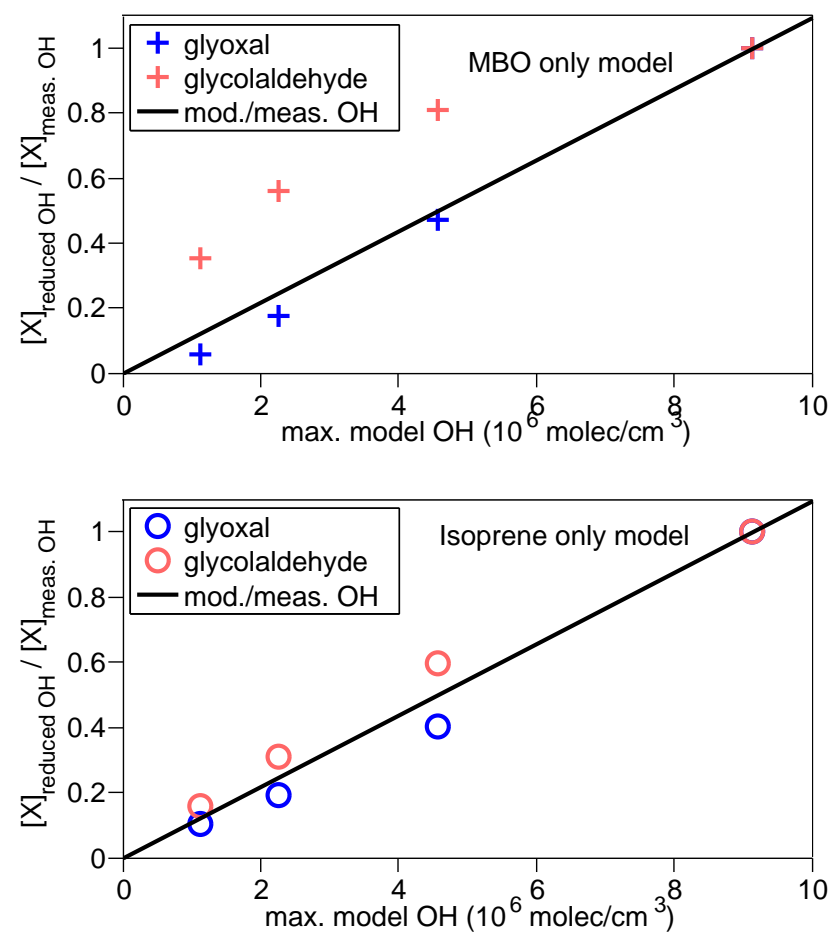

Fig. 5. The fractional reduction in glyoxal and glycolaldehyde concentration for models using either measured $\mathrm{OH}$ or reduced $\mathrm{OH}$ during the hot period. The top panel shows results using only $\mathrm{MBO}$ chemistry, and demonstrates that glyoxal is correlated to $\mathrm{OH}$ concentration while glycolaldehyde (a first generation product of $\mathrm{MBO}$ ) shows less dependence on $\mathrm{OH}$. In the bottom panel, the results of isoprene oxidiation for the same changes in $\mathrm{OH}$ concentration are shown. Here, glyoxal and glycolaldehyde (both of which are mainly higher-generation products of isoprene oxidation) approximately follow changes in $\mathrm{OH}$. The change in glyoxal is slightly more than 1:1 while that of glycolaldehyde is slightly less.

\subsubsection{Reduced $\mathrm{OH}$ radical concentrations}

Another means of reducing model glyoxal concentration is to alter the overall oxidation process via changes to $\mathrm{OH}$ radical abundance. The average reduction in glycolaldehyde and glyoxal upon reducing $\mathrm{OH}$ is shown in Fig. 5. In the top panel, which shows simulated MBO chemistry, glyoxal responded slightly more than linearly to reductions in $\mathrm{OH}$ while glycolaldehyde responded less strongly. In the bottom panel, which shows simulated isoprene chemistry, both glycolaldehyde and glyoxal responded approximately linearly to reductions in $\mathrm{OH}$, with the response in glyoxal slightly stronger. Thus we demonstrate that glyoxal concentrations are very sensitive to $\mathrm{OH}$ levels; results of a model run using $\mathrm{MBO}$ and isoprene in which $\mathrm{OH}$ was reduced by a factor of two are presented in Fig. 6. Using half measured $\mathrm{OH}$ reduced the over-prediction of daytime glyoxal, defined as $0.35-0.8 \mathrm{~d}$, or 8:30-19:00 h, from $\sim 140 \%$ to $\sim 10 \%$, a reduction of glyoxal of slightly more than a factor of two. While this analysis 


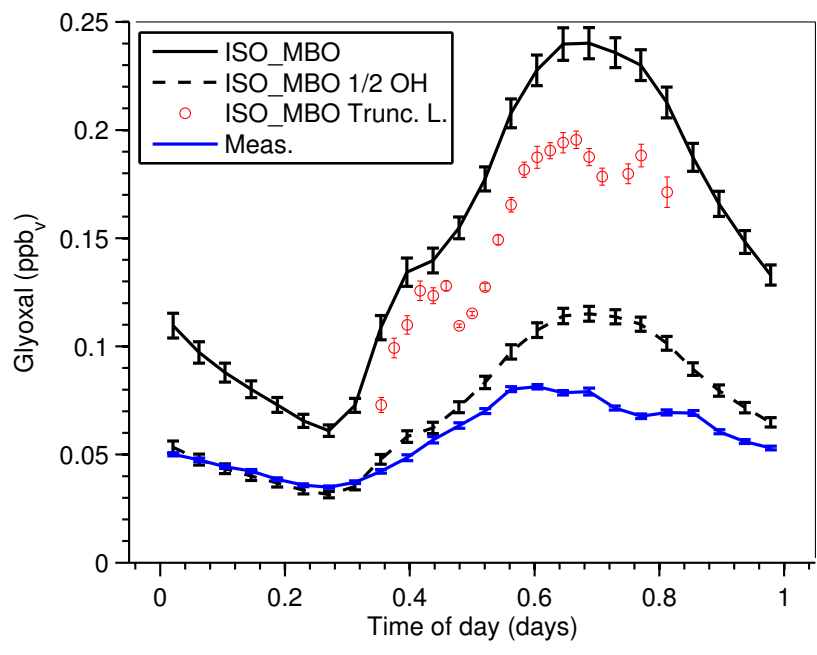

Fig. 6. Model results for $\mathrm{OH}$ sensitivity study. Simulations were performed using measured $\mathrm{OH}$ and $1 / 2$ measured $\mathrm{OH}$ using combined isoprene and MBO chemistry. The Truncated Lagrangian model (daytime only) is shown for comparison. Error bars indicate the 1 standard deviation envelope as calculated based on the variability in the data and model outputs, not reported errors.

will focus on daytime chemistry, we note that nighttime production of glyoxal in the model is mediated almost entirely by $\mathrm{OH}$, which may lead to changes in the deposition velocity needed in the model, but will not change the observed rate described in Sect. 3.2. The reduced $\mathrm{OH}$ improved the daytime model over-prediction of $\mathrm{HO}_{2}$ from $\sim 64 \%$ to $\sim 14 \%$. Thus, reducing $\mathrm{OH}$ to slow overall photochemistry was very effective at improving model agreement with glyoxal and $\mathrm{HO}_{2}$. A potential instrumental artifact which would influence this analysis is the possibility of a positive bias in $\mathrm{HO}_{2}$ measurements due to interference by hydroxylalkyl peroxy radicals (Fuchs et al., 2011). As no specific information is available for the BFRS site in 2007 concerning this interference, no correction was attempted. However, it is possible that this affects our model-measurement comparison of $\mathrm{HO}_{2}$ and hence care should be taken in using the modelmeasurement agreement of $\mathrm{HO}_{2}$ as a metric for success in representing oxidation. The implied lower $\mathrm{OH}$ concentration refers to the $\mathrm{OH}$ concentration experienced over the lifetime of glyoxal and not necessarily the $\mathrm{OH}$ concentration at the measurement site. However, there is no reason to expect the $\mathrm{OH}$ concentrations to vary substantially in space over the distance relevant to the glyoxal lifetime.

It is worth discussing the merits of this sensitivity analysis, as the implications are important within the context of the disagreements between modeled and measured $\mathrm{OH}$ discussed in the introduction. The validity of a factor 2 reduction of the $\mathrm{OH}$ concentration in the model compared to the reported measurements appears questionable given the measurement absolute accuracy of $32 \%, 2 \sigma$. Preliminary results from a recent study by the PSU group during BEARPEX 2009 suggest that the measured daytime $\mathrm{OH}$ concentrations at this site could potentially be a factor of 2.5 lower than determined with the traditional measurement method used during BEARPEX 2007 (Brune et al., 2010). The results of our sensitivity analysis showed that reducing $\mathrm{OH}$ concentrations was one of the most effective means of reducing the glyoxal and $\mathrm{HO}_{2}$ over-predictions and this adjustment, which is in general agreement with the preliminary findings of Brune et al. (2010), had a larger effect than any of the previously discussed parameters; at present, none of these other methods we employed to reduce glyoxal are corroborated in scientific literature.

LaFranchi et al. (2009) found that calculated steady-state concentrations of APNs were as much as two times measured values for the hot period of BEARPEX 2007, despite the fact that the steady-state model is expected to work well under these conditions. The authors attributed this to uncertainties in the chemistry of peroxy radicals, noting that a factor of three increase in the reaction rate of acyl peroxy radicals with $\mathrm{RO}_{2}$ greatly improved model-measurement agreement. Reducing $\mathrm{OH}$ radical concentrations represents another potential solution, as this would decrease the production rate of acyl peroxy radicals.

\subsubsection{Truncated-Lagrangian-transport model}

Transport of glyoxal was not treated explicitly in the 0-D box model. This shortcoming can affect model glyoxal concentrations differently depending on whether the glyoxal precursors are emitted primarily locally, such as MBO, or primarily upwind of the measurement site, as is the case for isoprene. The 0-D model will overestimate glyoxal production for the former case and underestimate it for the latter: MBO is only emitted in a fairly limited spatial region upwind of the measurement site. Whereas in the box model afternoon air masses experienced MBO processing all day, in reality they only experienced $\mathrm{MBO}$ emissions with subsequent oxidation to glyoxal for a few hours. Major emissions of isoprene occur at a distance from the measurement site and isoprene is already substantially processed $(>50 \%)$ when it arrived at the site. Using the isoprene concentrations observed at the measurement site will under-predict the amount of oxidation products from isoprene, which can be seen in the MVK (and MACR) data shown in Fig. 7. As the daytime lifetime of glyoxal is $\sim 1 \mathrm{~h}$, the lack of inclusion of advection in the model is expected to have a limited effect, as transport of $3 \mathrm{~h}$ (the noon transport time to the measurement site from the zone where isoprene emissions give way to MBO emissions) will have lost most of the original glyoxal. As the 0-D model predicted too much glyoxal, we investigated what the largest possible reduction in over-prediction as a result of transport could be. In this approach we addressed the overestimate resulting from the locally emitted $\mathrm{MBO}$ and neglected the 
underestimate resulting from isoprene. This represents an upper-limit of the effect of transport.

Using emission maps from Steiner et al. (2007) and measured wind speeds, we calculated the time that air at BFRS is influenced by MBO, for example $\sim 3 \mathrm{~h}$ at midday. We constructed a truncated-Lagrangian model in which the Lagrangian model run was initialized when an airmass with very low glyoxal and glycolaldehyde concentrations $\left(1 \times 10^{5}\right.$ moleculecm $\left.^{-3}\right)$ entered the MBO emitting area, where it experienced the chemical environment $(\mathrm{OH}$, $\mathrm{O}_{3}$, photolysis, etc.) measured at or calculated for the BEARPEX site. For example: the point at noon was estimated to need $3.12 \mathrm{~h}$ of transit time to reach the site from the edge of major MBO emissions, so the model concentration of glycolaldehyde was set very low at $8.88 \mathrm{~h}$ during each day of the simulation. In this case, air with little glyoxal and glycolaldehyde entered the box at time $=8.88 \mathrm{~h}$. The air-mass then moved with the measured wind-speeds up to the measurement site, which it reached at noon, and the final value then represents the noon-time model value at the measurement site. Similar runs were performed for each half hour interval. The emission maps show that MBO emissions are fairly homogeneous throughout this region and thus we used the measured MBO concentrations, the most important glyoxal precursor for the entire transect. Site measurements were also used to constrain the other parameters, such as isoprene. As discussed above this is incorrect for isoprene, which has higher concentrations at the entry to the MBO emitting area than our model assumed, and hence would increase glyoxal concentration.

The effect of transport with this truncated Lagrangian model was tested using isoprene and MBO as precursors, which capture $90 \%$ of model glyoxal production in the hot period. The upslope wind-flow lasted from about 0.3 day to 0.8 day (7-19h) on average; no data points are thus reported outside that time. The resultant set of half-hourly endpoints represent the daytime diurnal profile, with the influence of transport reduced or removed (assuming that air entered the $\mathrm{MBO}$ emission region with very low or zero concentration of these species). A dot is shown in Fig. 6, corresponding to the endpoints of each of these model runs. Glycolaldehyde was on average reduced to $86 \%$ of the original model level (not shown). This suggests that modeled concentrations of glycolaldehyde were only moderately too high due to the failure of the model to treat transport, and hence the 0-D model is not a bad approximation for modeling glycolaldehyde. The effect on glyoxal (which the model predicts is largely an oxidation product of glycolaldehyde) was more pronounced, as production of glyoxal from $\mathrm{MBO}$ requires two reactions with $\mathrm{OH}$ while glycolaldehyde production from MBO needs only one. MBO was the dominant precursor of glycolaldehyde and glyoxal in this simulation. As glyoxal is a secondary product its appearance had a lag compared to that of glycolaldehyde. Due to the limited model run time, this made the effect on glyoxal more pronounced than for glycolalde-

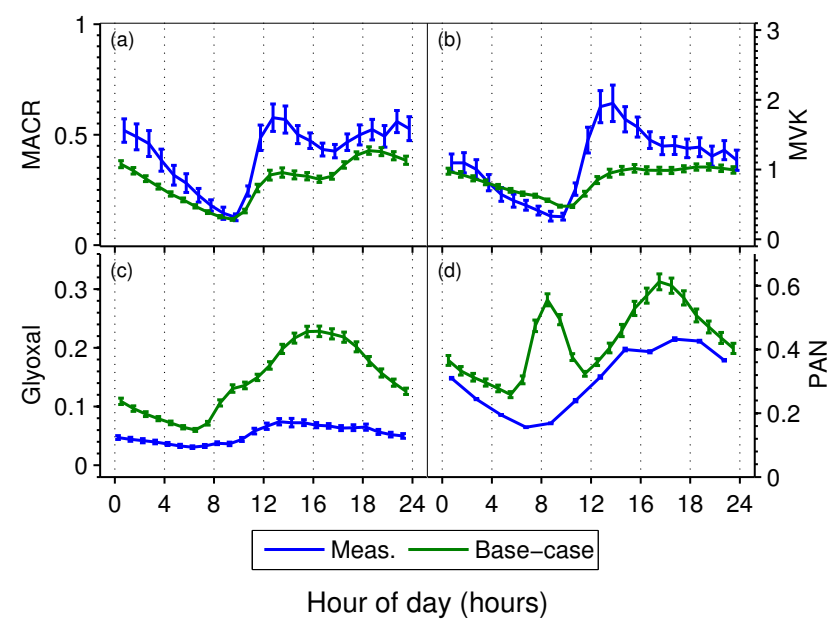

Fig. 7. Summary of model OVOCs and measurements as available, all in ppb. The model is broadly able to predict MVK and MACR, while it exceeds measurements of glyoxal substantially. The slight under-prediction of MVK and MACR is expected for the 0-D-box model as it underestimates the contribution of isoprene oxidation, which is largely emitted upwind of the measurement site. Error bars indicate the 1 standard deviation envelope as calculated based on the variability in the data, not reported errors.

hyde. However, the average reduction to $73 \%$ of the original glyoxal prediction was not sufficient to bring the model into agreement with measurement. For this reason, we conclude that transport alone is clearly not sufficient to explain the over-prediction in modeled glyoxal. In fact, the effect is likely to be smaller, as glyoxal from isoprene is underestimated.

\subsection{Discussion}

Analysis of the model results showed that the majority of glyoxal was formed by glycolaldehyde, which in turn was produced mainly from MBO, and to a lesser degree from isoprene and methylchavicol, which is in agreement with the fact that the glyoxal yield from MBO is substantially higher than from isoprene. The model included all main known precursors for glyoxal that were measured during BEARPEX 2007 and introduced methylchavicol as an additional one. The model substantially ( $\sim$ factor 2.5 ) over-predicted glyoxal at the measurement site. As MBO contributed $\sim 70 \%$ of glyoxal, MBO oxidation also had to contribute the majority of the over-prediction. An upper-limit estimate of the effect of transport on MBO processing improved modelmeasurement disagreement but still had a substantial overprediction ( $\sim$ factor 1.8$)$. The slight improvement was a result of the short lifetime of glyoxal during BEARPEX 2007, which limited the effect of transport and supports the notion that glyoxal is a "local" tracer of VOC oxidation chemistry. The effect of transport is expected to be diminished in the model due to the underestimation of glyoxal from isoprene. 
It is more likely that transport should increase glyoxal due to advection of precursors such as glycolaldehyde (from isoprene) which has approximately twice the lifetime of glyoxal. Other factors that could reduce the over-prediction are increased aerosol loss and a reduced yield of glyoxal from glycolaldehyde. The latter seems unlikely as the work done by Chan et al. (2009) used the Madison LIP instrument to parameterize glyoxal from glycolaldehyde. Since aerosol formation is proportional to liquid water content, the very dry conditions at BEARPEX eliminate aerosol as a significant sink. By far the most effective means to reduce the model over-prediction was reducing the $\mathrm{OH}$ concentration, which in addition was the only one supported by other evidence, i.e. the recent work by Brune et al. (2010). In addition, this was the only parameter that also resulted in a substantial improvement of modeled $\mathrm{HO}_{2}$ concentrations. The high sensitivity of glyoxal to $\mathrm{OH}$ is interesting as one might expect $\mathrm{OH}$ levels to have little effect on glyoxal as it participates in both production and destruction of glyoxal. The high sensitivity in our model stemmed from three details of the underlying chemical mechanism and model: (1) the model was driven with measured BVOC concentrations, not emissions, and hence increased $\mathrm{OH}$ resulted directly in increased glycolaldehyde, (2) glyoxal is largely a higher-generation product of BVOC oxidation and thus increased $\mathrm{OH}$ increases production of the precursor glycolaldehyde and how fast it is converted to glyoxal, and (3) reaction with $\mathrm{OH}$ was not the dominant glyoxal loss channel. Clearly, a combination of adjustment of different parameters could be employed to further improve the model to measurement disagreement. However, such combinations without reduction in $\mathrm{OH}$ are not sufficient to reduce modelled glyoxal while, for example, maintaining the correct shape of the diurnal cycle.

\section{Conclusions}

We present the first high time resolution glyoxal data obtained with a direct, in situ detection method in a rural region dominated by BVOC emissions. Measurements of glyoxal during the BEARPEX 2007 campaign were used to examine the influence of BVOCs on glyoxal production and we conclude that during the hot period glyoxal production was dominated by BVOCs. This is supported by the fact that the site is in a region with much higher BVOC than anthropogenic VOC concentrations during high temperature periods combined with the fact that the daytime lifetime of glyoxal is substantially shorter than the transport time from the edge of this region. This is further supported by comparison between hot and cold period glyoxal concentrations. In addition, a photochemical model showed that most of hot period glyoxal production resulted from BVOCs, primarily MBO and isoprene with a small contribution from methylchavicol, a species that had not previously been taken into account for glyoxal production.

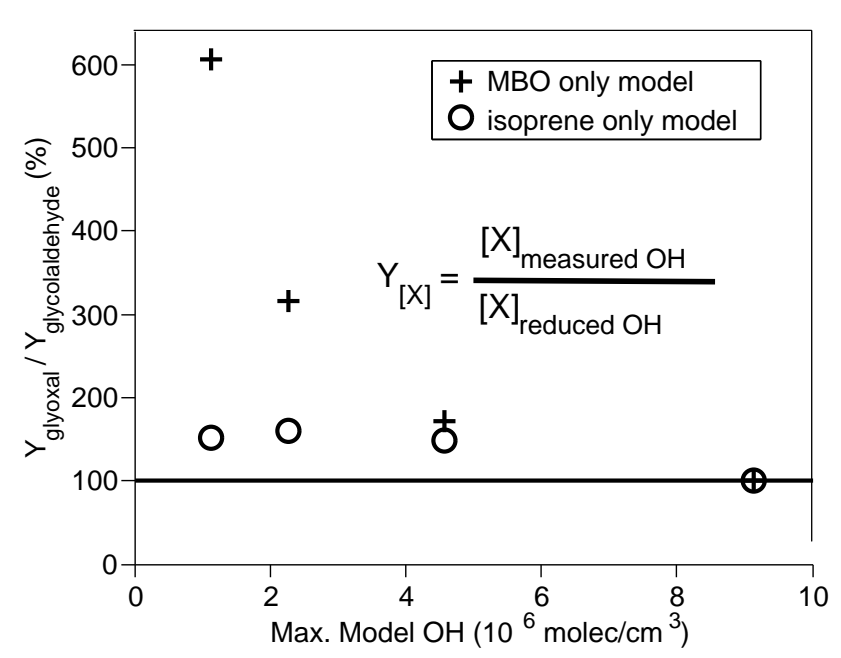

Fig. 8. The ratio of the response function $Y$ of glyoxal for models using either measured $\mathrm{OH}$ or reduced $\mathrm{OH}$ to the response function $\mathrm{Y}$ of glycolaldehyde for the hot period. These results show that for MBO chemistry, glyoxal becomes increasingly more sensitive than glycolaldehyde to $\mathrm{OH}$ concentration as $\mathrm{OH}$ decreases. In isoprene chemistry, glyoxal is always more sensitive than glycolaldehyde (above $100 \%$ ) but the magnitude and the trend are less pronounced.

In contrast to the recent work on formaldehyde by Choi et al. (2010a), no evidence was found that glyoxal is produced via oxidation of unknown/missing BVOC emissions during the hot period. However, this does not imply that such BVOC emissions do not exist, as only some BVOCs produce glyoxal, whereas formaldehyde is a much more common oxidation product. In addition, the glyoxal observed during the intermediate period cannot be explained with the VOCs measured at BFRS and hence it could indicate an unknown precursor for glyoxal.

Globally, biogenic sources of glyoxal are predicted to exceed anthropogenic sources, so measurements in rural areas are important and we present the first detailed dataset of its kind. This data is also of interest to comparison with modeling studies of glyoxal despite the limitations of measurements at a single ground site as it presents an analysis of the processes controlling glyoxal concentrations in a biogenically influenced area. Thus, the work contributes to the broader understanding of the tropospheric chemistry of glyoxal.

The results of a photochemical model that was successfully tested using chamber studies of isoprene and MBO oxidation were compared to data taken during BEARPEX 2007 showing a substantial over-prediction despite the reduction of higher-generation yields of glyoxal from isoprene. An attempt to model the influence of MBO chemistry more realistically by making an upper-limit estimate of the effect of transport showed that this only contributed to a small degree to the over-prediction as did loss of glyoxal to aerosol. 
A reduction of $\mathrm{OH}$ concentrations was determined to be by far the most effective way to reduce glyoxal model concentrations, and in addition was the only adjustment that has supporting evidence based on the recent work by Brune et al. (2010) and improved model $\mathrm{HO}_{2}$ concentrations. This demonstrates that glyoxal can be a useful local tracer of $\mathrm{OH}-$ driven VOC oxidation chemistry, in particular given its short photochemical lifetime. For example, the relative sensitivity of glyoxal and glycolaldehyde to changes in $\mathrm{OH}$ is shown in Fig. 8, which demonstrates that glyoxal is more sensitive (i.e. has a greater reduction for reduced $\mathrm{OH}$ ) than glycolaldehyde for both isoprene and MBO oxidation. The sensitivity is especially enhanced for the case of MBO, in which glycolaldehyde is a first generation product and glyoxal is a highergeneration product, but remains even for isoprene in which both are mainly higher-generation products. Our analysis has shown that glyoxal concentrations are more sensitive to $\mathrm{OH}$ than other BVOC oxidation products as it is predominantly a secondary product of mainly OH-driven BVOC oxidation, rather than $\mathrm{O}_{3}$-driven chemistry, combined with the fact that photolysis is usually more important as a sink than reaction with $\mathrm{OH}$. We propose that glyoxal is a useful tracer for $\mathrm{OH}$-driven BVOC oxidation chemistry.

\section{Supplementary material related to this article is available online at: \\ http://www.atmos-chem-phys.net/11/8883/2011/ acp-11-8883-2011-supplement.pdf.}

Acknowledgements. The authors gratefully acknowledge the support of the University of Wisconsin-Madison Department of Chemistry. The authors would like to thank Sierra Pacific Industries for the use of their land and the University of California, Berkeley, Center for Forestry, Blodgett Forest Research Station for cooperation in facilitating this research. This work was supported by the Camille and Henry Dreyfus Foundation, a National Defense Science and Engineering Graduate Fellowship (NDSEG) funded by the Army Research Office (ARO) and NSF ATM 0852406. Development of the Madison-LIP instrument and measurements during BEARPEX 2007 were supported by NSF ATM 0724912, and the NDSEG-ARO. The NOAA GC-MS measurements were supported by the National Science Foundation, Division of Atmospheric Sciences (grant 0516610). DKF, KSD, MJC and JLJ were supported by NSF ATM 0449815 \& ATM 0919189, and a NOAA postdoctoral fellowship to DKF. A. H. G. and N. C. B.-B. were supported by NSF ATM 0922562.

Edited by: A. B. Guenther

\section{References}

Archibald, A. T., Cooke, M. C., Utembe, S. R., Shallcross, D. E., Derwent, R. G., and Jenkin, M. E.: Impacts of mechanistic changes on $\mathrm{HO}_{\mathrm{x}}$ formation and recycling in the oxidation of isoprene, Atmos. Chem. Phys., 10, 8097-8118, doi:10.5194/acp10-8097-2010, 2010.

Bates, D. V.: Detection of chronic respiratory bronchiolitis in oxidant-exposed populations: analogy to tobacco smoke exposure, Environ. Health Perspect., 101(4), 217, 1993.

Bloss, C., Wagner, V., Bonzanini, A., Jenkin, M. E., Wirtz, K., Martin-Reviejo, M., and Pilling, M. J.: Evaluation of detailed aromatic mechanisms (MCMv3 and MCMv3.1) against environmental chamber data, Atmos. Chem. Phys., 5, 623-639, doi:10.5194/acp-5-623-2005, 2005a.

Bloss, C., Wagner, V., Jenkin, M. E., Volkamer, R., Bloss, W. J., Lee, J. D., Heard, D. E., Wirtz, K., Martin-Reviejo, M., Rea, G., Wenger, J. C., and Pilling, M. J.: Development of a detailed chemical mechanism (MCMv3.1) for the atmospheric oxidation of aromatic hydrocarbons, Atmos. Chem. Phys., 5, 641-664, doi:10.5194/acp-5-641-2005, 2005b.

Bouvier-Brown, N. C., Goldstein, A. H., Worton, D. R., Matross, D. M., Gilman, J. B., Kuster, W. C., Welsh-Bon, D., Warneke, C., de Gouw, J. A., Cahill, T. M., and Holzinger, R.: Methyl chavicol: characterization of its biogenic emission rate, abundance, and oxidation products in the atmosphere, Atmos. Chem. Phys., 9, 2061-2074, doi:10.5194/acp-9-2061-2009, 2009.

Brune, W. H., van Duin, D., Mao, J., and Ren, X.: OH and $\mathrm{HO}_{2}$ Measurements in Blodgett Forest, CA during BEARPEX 2009, American Geophysical Union Fall Meeting 2010, 13-17 December, San Francisco, California, USA, 2010.

Carlton, A. G., Turpin, B. J., Altieri, K. E., Seitzinger, S., Reff, A., Lim, H. J., and Ervens, B.: Atmospheric oxalic acid and SOA production from glyoxal: results of aqueous photooxidation experiments, Atmos. Environ., 41, 7588-7602, 2007.

Carlton, A. G., Wiedinmyer, C., and Kroll, J. H.: A review of Secondary Organic Aerosol (SOA) formation from isoprene, Atmos. Chem. Phys., 9, 4987-5005, doi:10.5194/acp-9-4987-2009, 2009.

Chan, A. W. H., Galloway, M. M., Kwan, A. J., Chhabra, P. S., Keutsch, F. N., Wennberg, P. O., Flagan, R. C., and Seinfeld, J. H.: Photooxidation of 2-methyl-3-buten-2-ol (MBO) as a potential source of secondary organic aerosol, Environ. Sci. Technol., 43, 4647-4652, doi:10.1021/es802560w, 2009.

Choi, W., Faloona, I. C., Bouvier-Brown, N. C., McKay, M., Goldstein, A. H., Mao, J., Brune, W. H., LaFranchi, B. W., Cohen, R. C., Wolfe, G. M., Thornton, J. A., Sonnenfroh, D. M., and Millet, D. B.: Observations of elevated formaldehyde over a forest canopy suggest missing sources from rapid oxidation of arboreal hydrocarbons, Atmos. Chem. Phys., 10, 8761-8781, doi:10.5194/acp-10-8761-2010, 2010a.

Choi, W., Faloona, I. C., McKay, M., Goldstein, A. H., and Baker, B.: Estimating the atmospheric boundary layer height over sloped, forested terrain from surface spectral analysis during BEARPEX, Atmos. Chem. Phys., 11, 6837-6853, doi:10.5194/acp-11-6837-2011, 2011 b.

Claeys, M., Graham, B., Vas, G., Wang, W., Vermeylen, R., Pashynska, V., Cafmeyer, J., Guyon, P., Andreae, M. O., Artaxo, P., and Maenhaut, W.: Formation of secondary organic aerosols 
through photooxidation of isoprene, Science, 303, 1173-1176, doi:10.1126/science.1092805, 2004.

Corrigan, A. L., Hanley, S. W., and De Haan, D. O.: Uptake of glyoxal by organic and inorganic aerosol, Environ. Sci. Technol., 42, 4428-4433, doi:10.1021/es7032394, 2008.

Dillon, M. B., Lamanna, M. S., Schade, G. W., Goldstein, A. H., and Cohen, R. C.: Chemical evolution of the Sacramento urban plume: transport and oxidation, J. Geophys. Res., 107(D5), 4045, doi:10.1029/2001JD000969, 2002.

Edney, E. O., Kleindienst, T. E., Jaoui, M., Lewandowski, M., Offenberg, J. H., Wang, W., and Claeys, M.: Formation of 2methyl tetrols and 2-methylglyceric acid in secondary organic aerosol from laboratory irradiated isoprene/ $\mathrm{NO}_{\mathrm{x}} / \mathrm{SO}_{2} /$ air mixtures and their detection in ambient $\mathrm{PM}_{2.5}$ samples collected in the Eastern United States, Atmos. Environ., 39, 5281-5289, doi:10.1016/j.atmosenv.2005.05.031, 2005.

Ervens, B. and Volkamer, R.: Glyoxal processing by aerosol multiphase chemistry: towards a kinetic modeling framework of secondary organic aerosol formation in aqueous particles, Atmos. Chem. Phys., 10, 8219-8244, doi:10.5194/acp-10-8219-2010, 2010.

Fares, S., McKay, M., Holzinger, R., and Goldstein, A. H.: Ozone fluxes in a Pinus ponderosa ecosystem are dominated by non-stomatal processes: Evidence from long-term continuous measurements, Agr. For. Meteorol., 150, 420-431, doi:10.1016/j.agrformet.2010.01.007, 2010.

Fu, T.-M., Jacob, D. J., Wittrock, F., Burrows, J. P., Vrekoussis, M., and Henze, D. K.: Global budgets of atmospheric glyoxal and methylglyoxal, and implications for formation of secondary organic aerosols, J. Geophys. Res., 113, D15303, doi:10.1029/2007JD009505, 2008.

Fuchs, H., Bohn, B., Hofzumahaus, A., Holland, F., Lu, K. D., Nehr, S., Rohrer, F., and Wahner, A.: Detection of $\mathrm{HO}_{2}$ by laserinduced fluorescence: calibration and interferences from $\mathrm{RO}_{2}$ radicals, Atmos. Meas. Tech., 4, 1209-1225, doi:10.5194/amt4-1209-2011, 2011.

Galloway, M. M., Chhabra, P. S., Chan, A. W. H., Surratt, J. D., Flagan, R. C., Seinfeld, J. H., and Keutsch, F. N.: Glyoxal uptake on ammonium sulphate seed aerosol: reaction products and reversibility of uptake under dark and irradiated conditions, Atmos. Chem. Phys., 9, 3331-3345, doi:10.5194/acp-9-3331-2009, 2009.

Galloway, M. M., Huisman, A. J., Yee, L. D., Chan, A. W. H., Loza, C. L., Seinfeld, J. H., and Keutsch, F. N.: Yields of oxidized volatile organic compounds during the $\mathrm{OH}$ radical initiated oxidation of isoprene, methyl vinyl ketone, and methacrolein under high- $\mathrm{NO}_{\mathrm{x}}$ conditions, Atmos. Chem. Phys. Discuss., 11, 10693-10720, doi:10.5194/acpd-11-10693-2011, 2011.

Goldstein, A. H. and Galbally, I. E.: Known and unexplored organic constituents in the Earth's atmosphere, Environ. Sci. Technol., 41, 1514-1521, doi:10.1021/es072476p, 2007

Goldstein, A. H., Hultman, N. E., Fracheboud, J. M., Bauer, M. R., Panek, J. A., Xu, M., Qi, Y., Guenther, A. B., and Baugh, W.: Effects of climate variability on the carbon dioxide, water, and sensible heat fluxes above a ponderosa pine plantation in the Sierra Nevada (CA), Agr. Forest Meteorol., 101, 113-129, doi:10.1016/S0168-1923(99)00168-9, 2000.

de Gouw, J. A., Middlebrook, A. M., Warneke, C., Goldan, P. D., Kuster, W. C., Roberts, J. M., Fehsenfeld, F. C., Worsnop, D. R.,
Canagaratna, M. R., Pszenny, A. A. P., Keene, W. C., Marchewka, M., Bertman, S. B., and Bates, T. S.: Budget of organic carbon in a polluted atmosphere: results from the New England Air Quality Study in 2002, J. Geophys. Res., 110, D16305, doi:10.1029/2004JD005623, 2005.

Guenther, A. B., Monson, R. K., and Fall, R.: Isoprene and monoterpene emission rate variability: observations with eucalyptus and emission rate algorithm development, J. Geophys. Res., 96, 10799-10808, 1991.

Guenther, A. B., Geron, C., Pierce, T., Lamb, B., Harley, P., and Fall, R.: Natural emissions of non-methane volatile organic compounds, carbon monoxide, and oxides of nitrogen from North America, Atmos. Environ., 34, 2205-2230, 2000.

Hallquist, M., Wenger, J. C., Baltensperger, U., Rudich, Y., Simpson, D., Claeys, M., Dommen, J., Donahue, N. M., George, C., Goldstein, A. H., Hamilton, J. F., Herrmann, H., Hoffmann, T., Iinuma, Y., Jang, M., Jenkin, M. E., Jimenez, J. L., KiendlerScharr, A., Maenhaut, W., McFiggans, G., Mentel, Th. F., Monod, A., Prévôt, A. S. H., Seinfeld, J. H., Surratt, J. D., Szmigielski, R., and Wildt, J.: The formation, properties and impact of secondary organic aerosol: current and emerging issues, Atmos. Chem. Phys., 9, 5155-5236, doi:10.5194/acp-95155-2009, 2009.

Herndon, S. C., Onasch, T. B., Wood, E. C., Kroll, J. H., Canagaratna, M. R., Jayne, J. T., Zavala, M. A., Knighton, W. B., Mazzoleni, C., Dubey, M. K., Ulbrich, I. M., Jimenez, J. L., Seila, R., de Gouw, J. A., de Foy, B., Fast, J., Molina, L. T., Kolb, C. E., and Worsnop, D. R.: Correlation of secondary organic aerosol with odd oxygen in Mexico City, Geophys. Res. Lett., 35, L15804, doi:10.1029/2008GL034058, 2008.

Hofzumahaus, A., Rohrer, F., Lu, K., Bohn, B., Brauers, T., Chang, C.-C., Fuchs, H., Holland, F., Kita, K., Kondo, Y., Li, X., Lou, S., Shao, M., Zeng, L., Wahner, A., and Zhang, Y.: Amplified trace gas removal in the troposphere, Science, 324, 1702 1704, 2009.

Holzinger, R., Lee, A., Paw, K. T., and Goldstein, U. A. H.: Observations of oxidation products above a forest imply biogenic emissions of very reactive compounds, Atmos. Chem. Phys., 5, 67-75, doi:10.5194/acp-5-67-2005, 2005.

Huisman, A. J., Hottle, J. R., Coens, K. L., Digangi, J. P., Galloway, M. M., Kammrath, A., and Keutsch, F. N.: Laser-induced phosphorescence for the in situ detection of glyoxal at part per trillion mixing ratios, Anal. Chem., 80, 5884-5891, 2008.

Intergovernmental Panel on Climate Change: Fourth Assessment Report: Climate Change 2007: Working Group I Report: The Physical Science Basis, Geneva: IPCC, available online at: http://www.ipcc.ch/ipccreports/ar4-wg1.htm,last access: 3 May 2011, 2007.

Jakab, G. J., Spannhake, E. W., Canning, B. J., Kleeberger, S. R., and Gilmour, M. I.: The effects of ozone on immune function, Environ. Health Perspect., 103(2), 77-89, 1995.

Jenkin, M. E., Saunders, S. M., and Pilling, M. J.: The tropospheric degradation of volatile organic compounds: a protocol for mechanism development, Atmos. Environ., 31, 81-104, doi:10.1016/S1352-2310(96)00105-7, 1997.

Karl, T., Harley, P., Emmons, L., Thornton, B., Guenther, A., Basu, C., Turnipseed, A., and Jardine, K.: Efficient atmospheric cleansing of oxidized organic trace gases by vegetation, Science, 330, 816-819, 2010. 
Karnosky, D. F., Gagnon, Z. E., Dickson, R. E., Coleman, M. D., Lee, E. H., and Isebrands, J. G.: Changes in growth, leaf abscission, and biomass associated with seasonal tropospheric ozone exposures of Populus tremuloides clones and seedlings, Can. J. For. Res., 26, 23-37, doi:10.1139/x26-003, 1996.

Kroll, J. H. and Seinfeld, J. H.: Chemistry of secondary organic aerosol: formation and evolution of low-volatility organics in the atmosphere, Atmos. Environ., 42, 3593-3624, 2008.

LaFranchi, B. W., Wolfe, G. M., Thornton, J. A., Harrold, S. A., Browne, E. C., Min, K. E., Wooldridge, P. J., Gilman, J. B., Kuster, W. C., Goldan, P. D., de Gouw, J. A., McKay, M., Goldstein, A. H., Ren, X., Mao, J., and Cohen, R. C.: Closing the peroxy acetyl nitrate budget: observations of acyl peroxy nitrates (PAN, PPN, and MPAN) during BEARPEX 2007, Atmos. Chem. Phys., 9, 7623-7641, doi:10.5194/acp-9-7623-2009, 2009.

Lamanna, M. S. and Goldstein, A. H.: In situ measurements of $\mathrm{C}_{2}-\mathrm{C}_{10}$ volatile organic compounds above a Sierra Nevada ponderosa pine plantation, J. Geophys. Res., 104(D17), 2124721262, 1999.

Lee, A., Goldstein, A. H., Kroll, J. H., Ng, N. L., Varutbangkul, V., Flagan, R. C., and Seinfeld, J. H.: Gas-phase products and secondary aerosol yields from the photooxidation of 16 different terpenes, J. Geophys. Res., 111, D17305, doi:10.5194/10.1029/2006JD007050, 2006.

Lelieveld, J., Butler, T. M., Crowley, J. N., Dillon, T. J., Fischer, H., Ganzeveld, L., Harder, H., Lawrence, M. G., Martinez, M., Taraborrelli, D., and Williams, J.: Atmospheric oxidation capacity sustained by a tropical forest, Nature, 452, 737-740, 2008.

Madronich, S. and Calvert, J. G.: Permutation reactions of organic peroxy radicals in the troposphere, J. Geophys. Res., 95(D5), 5697-5715, 1990.

Murphy, J. G., Day, D. A., Cleary, P. A., Wooldridge, P. J., Millet, D. B., Goldstein, A. H., and Cohen, R. C.: The weekend effect within and downwind of Sacramento - Part 1: Observations of ozone, nitrogen oxides, and VOC reactivity, Atmos. Chem. Phys., 7, 5327-5339, doi:10.5194/acp-7-5327-2007, 2007.

Myriokefalitakis, S., Vrekoussis, M., Tsigaridis, K., Wittrock, F., Richter, A., Brhl, C., Volkamer, R., Burrows, J. P., and Kanakidou, M.: The influence of natural and anthropogenic secondary sources on the glyoxal global distribution, Atmos. Chem. Phys., 8, 4965-4981, doi:10.5194/acp-8-4965-2008, 2008.

Nozière, B., Dziedzic, P., and Córdova, A.: Products and kinetics of the liquid-phase reaction of glyoxal catalyzed by ammonium ions $\left(\mathrm{NH}_{4}^{+}\right)$, J. Phys. Chem. A, 113, 231-237, 2008.

Orlando, J. J., Tyndall, G. S., Bertman, S. B., Chen, W., and Burkholder, J. B.: Rate coefficient for the reaction of $\mathrm{OH}$ with $\mathrm{CH}_{2}=\mathrm{C}\left(\mathrm{CH}_{3}\right) \mathrm{C}(\mathrm{O}) \mathrm{OONO}_{2}$ (MPAN), Atmos. Environ., 36, 1895-1900, 2002.

Paulot, F., Crounse, J. D., Kjaergaard, H. G., Kurten, A., St. Clair, J. M., Seinfeld, J. H., and Wennberg, P. O.: Unexpected epoxide formation in the gas-phase photooxidation of isoprene, Science, 325, 730-733, doi:10.1126/science.1172910, 2009.

Peeters, J. and Muller, J. F.: $\mathrm{HO}_{\mathrm{x}}$ radical regeneration in isoprene oxidation via peroxy radical isomerisations. II: Experimental evidence and global impact, Phys. Chem. Chem. Phys., 12, 1422714235, 2010.

Peeters, J., Nguyen, T. L., and Vereecken, L.: $\mathrm{HO}_{\mathrm{x}}$ radical regeneration in the oxidation of isoprene, Phys. Chem. Chem. Phys., 11, 5935-5939, 2009.
Percy, K. E., Awmack, C. S., Lindroth, R. L., Kubiske, M. E., Kopper, B. J., Isebrands, J. G., Pregitzer, K. S., Hendrey, G. R., Dickson, R. E., Zak, D. R., Oksanen, E., Sober, J., Harrington, R., and Karnosky, D. F.: Altered performance of forest pests under atmospheres enriched by $\mathrm{CO}_{2}$ and $\mathrm{O}_{3}$, Nature, 420, 403-407, doi:10.1038/nature01028, 2002.

Pérez, I. M., LaFranchi, B. W., and Cohen, R. C.: Nitrogen oxide chemistry in an urban plume: investigation of the chemistry of peroxy and multifunctional organic nitrates with a Lagrangian model, Atmos. Chem. Phys. Discuss., 9, 27099-27165, doi:10.5194/acpd-9-27099-2009, 2009.

Plummer, D. A., McConnell, J. C., Shepson, P. B., Hastie, D. R., and Niki, H.: Modeling of ozone formation at a rural site in Southern Ontario, Atmos. Environ., 30, 2195-2217, 1996.

Ren, X., Olson, J. R., Crawford, J. H., Brune, W. H., Mao, J., Long, R. B., Chen, Z., Chen, G., Avery, M. A., Sachse, G. W., Barrick, J. D., Diskin, G. S., Huey, L. G., Fried, A., Cohen, R. C., Heikes, B., Wennberg, P. O., Singh, H. B., Blake, D. R., and Shetter, R. E.: $\mathrm{HO}_{\mathrm{x}}$ chemistry during INTEX-A 2004: Observation, model calculation, and comparison with previous studies, J. Geophys. Res., 113, D05310, doi:10.1029/2007JD009166, 2008.

Saunders, S. M., Jenkin, M. E., Derwent, R. G., and Pilling, M. J.: Protocol for the development of the Master Chemical Mechanism, MCM v3 (Part A): tropospheric degradation of nonaromatic volatile organic compounds, Atmos. Chem. Phys., 3, 161-180, doi:10.5194/acp-3-161-2003, 2003.

Schade, G. W., Goldstein, A. H., Gray, D. W., and Lerdau, M. T.: Canopy and leaf level 2-methyl-3-buten-2-ol fluxes from a ponderosa pine plantation, Atmos. Environ., 34, 3535-3544, doi:10.1016/S1352-2310(00)00120-5, 2000.

Schlosser, E., Brauers, T., Dorn, H.-P., Fuchs, H., Häseler, R., Hofzumahaus, A., Holland, F., Wahner, A., Kanaya, Y., Kajii, Y., Miyamoto, K., Nishida, S., Watanabe, K., Yoshino, A., Kubistin, D., Martinez, M., Rudolf, M., Harder, H., Berresheim, H., Elste, T., Plass-Dülmer, C., Stange, G., and Schurath, U.: Technical Note: Formal blind intercomparison of $\mathrm{OH}$ measurements: results from the international campaign HOxComp, Atmos. Chem. Phys., 9, 7923-7948, doi:10.5194/acp-9-7923-2009, 2009.

Shapiro, E. L., Szprengiel, J., Sareen, N., Jen, C. N., Giordano, M. R., and McNeill, V. F.: Light-absorbing secondary organic material formed by glyoxal in aqueous aerosol mimics, Atmos. Chem. Phys., 9, 2289-2300, doi:10.5194/acp-9-2289-2009, 2009.

da Silva, G.: Hydroxyl radical regeneration in the photochemical oxidation of glyoxal: kinetics and mechanism of the $\mathrm{HC}(\mathrm{O}) \mathrm{CO}+$ $\mathrm{O}_{2}$ reaction, Phys. Chem. Chem. Phys., 12, 6698-6705, 2010.

Spaulding, R. S., Schade, G. W., Goldstein, A. H., and Charles, M. J.: Characterization of secondary atmospheric photooxidation products: evidence for biogenic and anthropogenic sources, J. Geophys. Res., 108, 4247, doi:10.1029/2002JD002478, 2003.

Stavrakou, T., Müller, J.-F., De Smedt, I., Van Roozendael, M., Kanakidou, M., Vrekoussis, M., Wittrock, F., Richter, A., and Burrows, J. P.: The continental source of glyoxal estimated by the synergistic use of spaceborne measurements and inverse modelling, Atmos. Chem. Phys., 9, 8431-8446, doi:10.5194/acp-9-8431-2009, 2009.

Stavrakou, T., Peeters, J., and Müller, J.-F.: Improved global mod- 
elling of $\mathrm{HO}_{\mathrm{x}}$ recycling in isoprene oxidation: evaluation against the GABRIEL and INTEX-A aircraft campaign measurements, Atmos. Chem. Phys., 10, 9863-9878, doi:10.5194/acp-10-98632010, 2010.

Steiner, A. L., Tonse, S., Cohen, R. C., Goldstein, A. H., and Harley, R. A.: Biogenic 2-methyl-3-buten-2-ol increases regional ozone and $\mathrm{HO}_{\mathrm{x}}$ sources, Geophys. Res. Lett., 34, L15806, doi:10.1029/2007GL030802, 2007.

Steiner, A. L., Cohen, R. C., Harley, R. A., Tonse, S., Millet, D. B., Schade, G. W., and Goldstein, A. H.: VOC reactivity in central California: comparing an air quality model to ground-based measurements, Atmos. Chem. Phys., 8, 351-368, doi:10.5194/acp-8351-2008, 2008.

Sumner, A. L., Shepson, P. B., Couch, T. L., Thornberry, T., Carroll, M. A., Sillman, S., Pippin, M., Bertman, S., Tan, D., Faloona, I., Brune, W., Young, V., Cooper, O., Moody, J., and Stockwell, W.: A study of formaldehyde chemistry above a forest canopy, J. Geophys. Res., 106(D20), 24387-24405, 2001.

Tan, D., Faloona, I., Simpas, J. B., Brune, W., Shepson, P. B., Couch, T. L., Sumner, A. L., Carroll, M. A., Thornberry, T., Apel, E., Riemer, D., and Stockwell, W.: $\mathrm{HO}_{\mathrm{x}}$ budgets in a deciduous forest: Results from the PROPHET summer 1998 campaign, J. Geophys. Res., 106(D20), 24407-24427, 2001.

Tan, Y., Perri, M. J., Seitzinger, S. P., and Turpin, B. J.: Effects of precursor concentration and acidic sulfate in aqueous glyoxal$\mathrm{OH}$ radical oxidation and implications for secondary organic aerosol, Environ. Sci. Technol., 43, 8105-8112, 2009.

Taraborrelli, D., Lawrence, M. G., Butler, T. M., Sander, R., and Lelieveld, J.: Mainz Isoprene Mechanism 2 (MIM2): an isoprene oxidation mechanism for regional and global atmospheric modelling, Atmos. Chem. Phys., 9, 2751-2777, doi:10.5194/acp-92751-2009, 2009.

Thornton, J. A., Wooldridge, P. J., Cohen, R. C., Martinez, M., Harder, H., Brune, W. H., Williams, E. J., Roberts, J. M., Fehsenfeld, F. C., Hall, S. R., Shetter, R. E., Wert, B. P., and Fried, A.: Ozone production rates as a function of $\mathrm{NO}_{\mathrm{x}}$ abundances and $\mathrm{HO}_{\mathrm{x}}$ production rates in the Nashville urban plume, J. Geophys. Res., 107, doi:10.1029/2001JC001083, 2002.

Trainer, M., Williams, E. J., Parrish, D. D., Buhr, M. P., Allwine, E. J., Westberg, H. H., Fehsenfeld, F. C., and Liu, S. C.: Models and observations of the impact of natural hydrocarbons on rural ozone, Nature, 329, 705-707, doi:10.1038/329705a0, 1987.

Volkamer, R., Jimenez, J. L., San Martini, F., Dzepina, K., Zhang, Q., Salcedo, D., Molina, L. T., Worsnop, D. R., and Molina, M. J.: Secondary organic aerosol formation from anthropogenic air pollution: rapid and higher than expected, Geophys. Res. Lett., 33, L17811, doi:10.1029/2006GL026899, 2006.

Volkamer, R., San Martini, F., Molina, L. T., Salcedo, D., Jimenez, J. L., and Molina, M. J.: A missing sink for gas-phase glyoxal in Mexico City: formation of secondary organic aerosol, Geophys. Res. Lett., 34, L19807, doi:10.1029/2007GL030752, 2007.
Volkamer, R., Ziemann, P. J., and Molina, M. J.: Secondary Organic Aerosol Formation from Acetylene $\left(\mathrm{C}_{2} \mathrm{H}_{2}\right)$ : seed effect on SOA yields due to organic photochemistry in the aerosol aqueous phase, Atmos. Chem. Phys., 9, 1907-1928, doi:10.5194/acp9-1907-2009, 2009.

Whalley, L. K., Edwards, P. M., Furneaux, K. L., Goddard, A., Ingham, T., Evans, M. J., Stone, D., Hopkins, J. R., Jones, C. E., Karunaharan, A., Lee, J. D., Lewis, A. C., Monks, P. S., Moller, S. J., and Heard, D. E.: Quantifying the magnitude of a missing hydroxyl radical source in a tropical rainforest, Atmos. Chem. Phys., 11, 7223-7233, doi:10.5194/acp-11-72232011, 2011.

Wolfe, G. M., Thornton, J. A., Yatavelli, R. L. N., McKay, M., Goldstein, A. H., LaFranchi, B., Min, K.-E., and Cohen, R. C.: Eddy covariance fluxes of acyl peroxy nitrates (PAN, PPN and MPAN) above a Ponderosa pine forest, Atmos. Chem. Phys., 9, 615-634, doi:10.5194/acp-9-615-2009, 2009.

Wolfe, G. M., Thornton, J. A., Bouvier-Brown, N. C., Goldstein, A. H., Park, J.-H., McKay, M., Matross, D. M., Mao, J., Brune, W. H., LaFranchi, B. W., Browne, E. C., Min, K.-E., Wooldridge, P. J., Cohen, R. C., Crounse, J. D., Faloona, I. C., Gilman, J. B., Kuster, W. C., de Gouw, J. A., Huisman, A., and Keutsch, F. N.: The Chemistry of Atmosphere-Forest Exchange (CAFE) Model - Part 2: Application to BEARPEX-2007 observations, Atmos. Chem. Phys., 11, 1269-1294, doi:10.5194/acp11-1269-2011, 2011.

Wood, E. C., Canagaratna, M. R., Herndon, S. C., Onasch, T. B., Kolb, C. E., Worsnop, D. R., Kroll, J. H., Knighton, W. B., Seila, R., Zavala, M., Molina, L. T., DeCarlo, P. F., Jimenez, J. L., Weinheimer, A. J., Knapp, D. J., Jobson, B. T., Stutz, J., Kuster, W. C., and Williams, E. J.: Investigation of the correlation between odd oxygen and secondary organic aerosol in Mexico City and Houston, Atmos. Chem. Phys., 10, 8947-8968, doi:10.5194/acp-10-8947-2010, 2010.

Zhang, Q., Jimenez, J. L., Canagaratna, M. R., Allan, J. D., Coe, H., Ulbrich, I., Alfarra, M. R., Takami, A., Middlebrook, A. M., Sun, Y. L., Dzepina, K., Dunlea, E., Docherty, K. S., DeCarlo, P. F., Salcedo, D., Onasch, T., Jayne, J. T., Miyoshi, T., Shimono, A., Hatakeyama, S., Takegawa, N., Kondo, Y., Schneider, J., Drewnick, F., Borrmann, S., Weimer, S., Demerjian, K., Williams, P., Bower, K., Bahreini, R., Cottrell, L., Griffin, R. J., Rautiainen, J., Sun, J. Y., Zhang, Y. M., and Worsnop, D. R.: Ubiquity and dominance of oxygenated species in organic aerosols in anthropogenically-influenced Northern Hemisphere midlatitudes, Geophys. Res. Lett., 34, L13801, doi:10.1029/2007GL029979, 2007. 